\title{
The provenance of Late Ediacaran and Early Ordovician siliciclastic rocks in the Southwest Central Iberian Zone: Constraints from detrital zircon data on northern Gondwana margin evolution during the late Neoproterozoic
}

\author{
M.F. Pereira ${ }^{\mathrm{a}, *}$, U. Linnemann $^{\mathrm{b}}$, M. Hofmann ${ }^{\mathrm{b}}$, M. Chichorro ${ }^{\mathrm{c}}$, A.R. Solá ${ }^{\mathrm{d}}$, J. Medina ${ }^{\mathrm{e}}$, J.B. Silva ${ }^{\mathrm{f}}$ \\ a IDL, Departamento de Geociências, ECT, Universidade de Évora, Apartado 94, 7001-554 Évora, Portugal \\ ${ }^{\mathrm{b}}$ Senckenberg Naturhistorische Sammlungen Dresden, Germany \\ c CICEGe, Faculdade de Ciências e Tecnologia, Universidade Nova de Lisboa, Quinta da Torre, 2829-516 Caparica, Portugal \\ ' LNEG, Unidade de Geologia e Cartografia Geológica, Portugal \\ e Departamento de Geociências, Universidade de Aveiro, Portugal \\ ${ }^{\mathrm{f}}$ IDL, Departamento de Geologia, FCUL, Portugal
}

\section{A R T I C L E I N F O}

\section{Article history:}

Received 7 February 2011

Received in revised form 14 October 2011

Accepted 28 October 2011

Available online 4 November 2011

\section{Keywords:}

Provenance analysis

Northern Gondwana margin

Avalonian-Cadomian magmatic arc

Central-Iberian Zone

West African

Amazonian cratons

\begin{abstract}
A B S T R A C T
U-Pb geochronology of detrital zircon from Late Ediacaran (Beiras Group greywackes) and Early Ordovician (Sarnelhas arkosic quartzites and Armorican quartzites of Penacova) sedimentary rocks of the southwest Central Iberian Zone (SW CIZ) constrain the evolution of northern Gondwana active-passive margin transition. The LA-ICP-MS U-Pb data set (375 detrital zircons with $90-110 \%$ concordant ages) is dominated by Neoproterozoic ages ( $75 \%$ for the greywakes and $60 \%$ for the quartzites), among which the main age cluster (more significant for Beiras Group greywackes) is Cryogenian (c.840-750 Ma), while a few Mesoproterozoic and Tonian ages are also present (percentages $<8 \%$ ). These two features, and the predominance of Cryogenian ages over Ediacaran ages, distinguish the Beiras Group greywackes (SW $\mathrm{CIZ}$ ) from the time-equivalent Serie Negra (Ossa-Morena Zone - OMZ), with which they are in inferred contact. The age spectra of the Beiras Group greywackes also reveal three major episodes of zircon crystallisation in the source area during the Neoproterozoic that are probably associated with a long-lived system of magmatism that developed either along or in the vicinity of the northern Gondwana margin at: (1) c. 850-700 Ma - Pan-African suture (not well represented in OMZ); (2) c. 700-635 Ma - early Cadomian arc; and (3) c. 635-545 Ma - late Cadomian arc. Comparison of Neoproterozoic ages and those of the Paleoproterozoic (c. 2-1.8 Ga) and Archean (mainly Neoarchean - 2.8-2.6 Ga, but also older) in the Beiras Group greywackes with U-Pb ages of Cadomian correlatives shows that: (1) SW CIZ, OMZ, SaxoThuringian Zone, North Armorican Cadomian Belt and Anti-Atlas) evolved together during the formation of back-arc basins on the northern Gondwana active margin and (2) all recorded synorogenic basins that were filled during the Ediacaran by detritus resulting from erosion of the West African craton, the PanAfrican suture and a long-lived Cadomian magmatic arc. Differences in detrital zircon age populations in the greywackes of the Beiras Group (SW CIZ Cadomian basement) and the Serie Negra (OMZ Cadomian basement) are also observed in their respective overlying Early Ordovician quartzites. Since both these SW Iberia Cadomian basements evolved together along the active margin of Gondwana (but sufficiently separated to account for the differences in their detrital zircon content), this continuation of differing zircon populations into the Early Ordovician suggests that the inferred contact presently juxtaposing the Beiras Group and the Serie Negra is not pre-Early Ordovician and so is unlikely to demonstrate a Cadomian suture.
\end{abstract}

(c) 2011 Elsevier B.V. All rights reserved.

\section{Introduction}

The basement rocks of Western and Central Europe were formed during the final stages of Gondwana assembly in the late

\footnotetext{
* Corresponding author.

E-mail address: mpereira@uevora.pt (M.F. Pereira).
}

Neoproterozoic (Murphy and Nance, 1991; Linnemann et al., 2004) (Figs. 1A and 2). In this context, Iberia occupies a critical role in enabling an understanding of the evolution of a Late Ediacaran active margin in North Gondwana and the subsequent transition to a passive margin in Cambrian-Ordovician times (Murphy et al., 2006a,b; Linnemann et al., 2008; Nance et al., 2008, 2010). Over the last two decades, advances in our knowledge of stratigraphy, deformation, geochemistry, isotope chemistry and geochronology have 